\title{
Peran lingkungan keluarga dalam mengembangkan wirausaha muda
}

\author{
Khofifatu Rohmah Adi \\ Fakultas Ilmu Sosial, Universitas Negeri Malang \\ Malang, Indonesia \\ khofifatu.rohmah.fis@um.ac.id \\ Idris \\ Fakultas Ilmu Sosial, Universitas Negeri Malang \\ Malang, Indonesia \\ Idris.fis@um.ac.id
}

\begin{abstract}
The development and maturity of a person's business is influenced by many factors. Many factors also influence the development of pilot businesses that are started and carried out by students. One of the factors that play an essential role in influencing young entrepreneurs can come from their parents or family environment. This article aims to identify and how the family's role in motivating and developing young entrepreneurs' potential. This research is a qualitative descriptive study. In-depth interviews carried out data collection. The data obtained were then analyzed using interactive analysis techniques, which consisted of 4 stages: data collection, data reduction, data presentation, and concluding. The results showed that entrepreneurial students who had sufficiently developed businesses received much support from their families. Parents' role as a form of support for their children in entrepreneurship is social, instrumental, emotional, and other support. The concrete form of this support is supported in providing facilities for business development, accompanying and assisting the business carried out by their children, giving permission and trust in children. These results can be used as knowledge and input to parents about how they should support children in entrepreneurship.
\end{abstract}

Keywords: Parents' role; Young entrepreneur

Abstrak: Perkembangan dan kematangan suatu usaha dari seseorang dipengaruhi oleh banyak faktor. Perkembangan usaha rintisan yang dimulai dan dilakukan oleh para mahasiswa tentu juga dipengaruhi oleh banyak faktor. Salah satu faktor yang berperan penting dalam mempengaruhi wirausaha muda bisa berasal dari orang tua, atau lingkungan keluarga. Artikel ini bertujuan untuk mengidentifikasi apa saja dan bagaimana peran keluarga dalam memotivasi dan mengembangkan potensi wirausaha muda. penelitian ini merupakan penelitian deskriptif kualitatif. Pengumpulan data dilakukan dengan wawancara secara mendalam. Data yang diperoleh kemudian dianalisis dengan Teknik analisis interaktif yang terdiri dari 4 tahap, yakni pengumpulan data, reduksi data, penyajian data, dan penarikan kesimpulan. Hasil penelitian menunjukkan bahwa para mahasiswa wirausaha yang memiliki usaha cukup berkembang memperoleh banyak dukungan dari keluarga mereka. Adapun peran orang tua sebagai bentuk 
dukungan terhadap anak-anak mereka dalam berwirausaha adalah dukungan sosial, instrumental, emosional, dan dukungan lainnya. Bentuk konkret dari dukungan tersebut adalah dukungan berupa pemberian fasilitas untuk pengembangan usaha, mendampingi dan membantu usaha yang dilakukan oleh anak mereka, memberi izin dan kepercayaan pada anak. Hasil ini dapat dijadikan sebagai pengetahuan serta masukan kepada para orang tua tentang bagaimana mereka harus bersikap dalam mendukung anak dalam berwirausaha.

Kata Kunci: peran keluarga; wirausahawan muda

Diterima 24 Maret 2021, Dipublikasikan April 2021

\section{PENDAHULUAN}

Topik tentang pengembangan wirausaha menjadi bahasan yang sangat penting karena berkaitan dengan usaha pembangunan ekonomi baik regional maupun nasional. Berbagai upaya telah dilakukan untuk merangsang munculnya wirausahawan-wirausahawan baru. Upaya tersebut seperti pendidikan kewirausahaan yang mulai diberikan pada tingkat sekolah, program-program semisal kompetisi bisnis yang dilakukan untuk para mahasiswa, dan pengalokasian anggaran yang dipergunakan khusus untuk menciptakan lebih banyak wirausaha. Usaha-usaha tersebut dilakukan karena pentingnya peran wirausaha bagi pembangunan ekonomi suatu negara. Pentingnya peran wirausaha dalam pembangunan perekonomian adalah dengan adanya wirausaha maka dapat mengatasi masalah-masalah problematik yang ada dalam perekonomian, seperti pengentasan kemiskinan, pengurangan jumlah pengangguran, penciptaan lapangan kerja baru dan lain sebagainya.

Adanya wirausaha dapat berperan secara signifikan terhadap kualitas diri masyarakat dan bangsa (Frinces, 2010). Kualitas hidup masyarakat dapat menjadi lebih baik dengan adanya peningkatan daya beli yang dapat diperoleh dari kegiatan berwirausaha. Peningkatan daya beli akan terjadi jika pendapatan yang diperoleh meningkat dari hasil profesi yang ditekuni. Wirausaha merupakan pilihan yang menjanjikan untuk dapat memperolehnya. hal ini juga dikuatkan oleh sejarah yang mana telah menyebut jika mayoritas negara-negara yang memiliki perekonomian maju merupakan negara-negara yang memiliki banyak wirausahawan. Dan, Idealnya jumlah wirausaha pada suatu negara adalah dua persen dari jumlah penduduk (Nagel, 2016)

Wirausaha muda merupakan bibit-bibit yang potensial untuk memajukan suatu bangsa. Dengan banyaknya wirausaha maka akan menyerap tenaga kerja dikemudian hari, selain itu banyaknya wirausaha juga turut menyumbang kenaikan pendapatan nasional. Jika pendapatan nasional meningkat maka artinya kesejahteraan suatu negara juga meningkat. Hal inilah yang pada akhirnya menjadi cita-cita negara Indonesia, sebagaimana yang termaktub dalam pembukaan Undang-Undang Dasar 1945 alinea ke IV yakni memajukan kesejahteraan umum.

Lingkungan di mana anak-anak tumbuh sangat mempengaruhi pola pikir dan perkembangannya. Salah satu lingkungan di mana anak-anak banyak menghabiskan waktu untuk bersosialisasi dan belajar adalah lingkungan keluarga. Keluarga memiliki peran yang sangat penting dalam mendampingi perkembangan anak-anak. Terlebih orang tua, Orang tua 


\section{Peran lingkungan keluarga dalam mengembangkan wirausaha muda}

dapat berperan sebagai pendidik, guru, motivator, supporter, fasilitator, dan sebagai model (Wahab, 2005). Orang tua sebagai pendidik dapat diartikan sebagai peran orang tua dalam mendidik anak yang memainkan peran penting dalam pembentukan pribadi dan moral anakanak, selain itu di sini orang tua dapat meletakkan dasar kecakapan hidup yang perlu dimiliki oleh anak. Dalam kegiatan sehari-hari orang tua dapat memainkan peran sebagai guru, orang tua dapat membelajarkan anak-anak tentang banyak hal yang digunakan untuk mempersiapkan anak-anak untuk mempersiapkan kegiatan di sekolah. Sebagai seorang motivator bagi anakanaknya dapat dilakukan dengan, mendorong dan memotivasi baik secara langsung maupun tidak langsung pada setiap kegiatan positif yang dilakukan anak-anak. Peran orang tua sebagai seorang supporter dapat dilakukan dengan memberikan baik dukungan secara moril maupun materiil. Peran fasilitator mengandung makna bahwa setiap orang tua harus mampu menyisihkan waktu, tenaga, dan kemampuannya untuk memfasilitasi segala kegiatan anak dalam proses perkembangannya. Orang tua sebagai model berarti orang tua dapat menjadi contoh dan teladan dalam berbagai aspek kecakapan dan perilaku yang dapat diikuti oleh anakanak.

Masalah yang terjadi saat ini adalah masih banyaknya orang tua yang menganggap bahwa wirausaha adalah jenis pekerjaan yang kurang bergengsi. Ratumbuysang \& Rasyid (2015) menyebut bahwa masih banyak orang tua yang tidak ingin anak mereka menjadi seorang wirausaha. Hal ini karena kurangnya pengetahuan orang tua tentang kewirausahaan. Bagi mereka kewirausahaan sama artinya dengan berdagang. Para orang tua ini lebih menginginkan anak-anak mereka menjadi pegawai perusahaan atau pegawai negeri. BKN menyebut bahwa pada tahun 2019 jumlah pelamar lebih dari 5 juta pendaftar, atau tepatnya 5.056.585 Pelamar (Liputan6.com, 2019). Dan jumlah pelamar ini dari tren data yang dimiliki BKN diketahui bahwa peminat dan pelamar seleksi CPNS memiliki tren cenderung meningkat tiap tahun. Namun, walaupun demikian saat ini banyak juga anak-anak muda yang memiliki usaha yang bisa dikatakan cukup berhasil, yang mana mungkin dengan kehadiran mereka dapat membuka pikiran orang tua tentang wirausaha.

Munculnya wirausaha-wirausaha muda ini juga tentu tidak terlepas dari pengaruh dan dukungan lingkungan, terutama lingkungan keluarga. Bagaimana peran keluarga khususnya orang tua dalam membentuk dan mendukung kewirausahaan anak, inilah yang akan kita bahas. Sehingga kita dapat mengetahui apa saja bentuk dukungan orang tua yang dapat memotivasi anak-anak sehingga membuat mereka untuk semangat dan tumbuh menjadi wirausahawan mandiri.

Penelitian sebelumnya oleh Setiabudi (2019) memperoleh hasil bahwa dukungan keluarga memiliki pengaruh positif terhadap niat berwirausaha. Hal ini mengandung makna bahwa semakin tinggi dukungan yang diberikan oleh lingkungan keluarga maka akan berdampak pada peningkatan niat berwirausaha anak. Penelitian serupa juga dilakukan oleh Periera, dkk (2017) yang memperoleh hasil bahwa dukungan keluarga mempengaruhi minat berwirausaha siswa SMK Strada Koja secara signifikan. artinya bahwa Ketika ada dukungan yang diberikan kepada 
anak-anak terhadap kewirausahaan maka minat anak-anak semakin tinggi terhadap kewirausahaan, hal ini tentu akan baik untuk karier berwirausaha anak-anak. Dari kedua penelitian tersebut dapat disimpulkan bahwa dukungan keluarga memiliki peran penting dalam mempengaruhi minat berwirausaha, namun kedua artikel tersebut masih sebatas mengetahui ada tidaknya pengaruh terhadap wirausaha. Tujuan dari artikel ini adalah untuk membahas lebih dalam tentang apa dan bagaimana bentuk-bentuk dukungan lingkungan sosial khususnya orang tua atau keluarga terhadap kegiatan wirausaha anak-anak mereka. Hal ini menjadi penting sebab akan dapat menjadi pengetahuan dan masukan kepada orang tua tentang bagaimana untuk mendukung kegiatan positif, khususnya berkaitan dengan kewirausahaan, sehingga dapat mengembangkan wirausaha anak-anak.

\section{METODE}

Penelitian ini didesain dengan menggunakan pendekatan kualitatif. Jenis penelitian ini adalah merupakan metode yang digunakan untuk mengeksplorasi serta memahami makna dari masalah sosial atau kemanusiaan (Creswell, 2015). Subyek penelitian ini adalah mahasiswa PIPS yang memiliki usaha mandiri dan orang tua yang memiliki anak-anak wirausaha. Metode pengumpulan data dilakukan dengan menggunakan teknik observasi dan wawancara secara mendalam. Observasi dilakukan untuk melihat keadaan sebenarnya dari kegiatan usaha yang dilakukan oleh mahasiswa. Sedangkan wawancara dilakukan untuk mengungkap data penting secara lebih detail dan mendalam. Data yang diperoleh kemudian dianalisis dengan teknik analisis yang diadopsi dari teknik analisis data yang dikembangkan oleh Miles dan Huberman (1992) yakni analisis model interaktif. Tahapan dalam analisis model interaktif adalah pengumpulan data, reduksi data, penyajian data, dan penarikan kesimpulan. Pengumpulan data dilakukan dengan observasi dan wawancara yang disusun tanpa adanya komentar dari peneliti. Reduksi data merupakan penyederhanaan dan mentrasformasikan data kasar dari penggalian data lapangan, pada tahap ini dilakukan memfokuskan pada data-data penting sehingga datadata dapat mengarah pada kesimpulan yang dianggap penting. Penyajian data dilakukan dalam bentuk uraian secara deskriptif. Terakhir penarikan kesimpulan dan verifikasi. Kesimpulan didapatkan dengan mencermati penjelasan, serta hubungan sebab akibat antar berbagai unsur fokus penelitian. Kesimpulan awal yang diambil masih bersifat sementara, selanjutnya kesimpulan awal ini diverifikasi dengan data dan bukti pendukung yang memperkuatnya. Hal ini dimaksudkan agar kesimpulan yang ambil kredibel.

\section{HASIL DAN PEMBAHASAN}

Perilaku berwirausaha yang dinampakkan oleh seseorang tidak lepas dari adanya pengaruh, baik pengaruh dari dalam diri seseorang maupun pengaruh dari luar seseorang. Adanya norma subyektif, sedikit banyak memberikan pengaruh seseorang dalam pengambilan keputusan dalam berperilaku. Norma subyektif merupakan tekanan sosial yang dirasakan seseorang untuk melakukan atau tidak melakukan sesuatu (Ajzen, 1991; Mahyarni, 2013). Lebih lanjut 


\section{Peran lingkungan keluarga dalam mengembangkan wirausaha muda}

Jogiyanto (2007) menyebut bahwa norma subyektif merupakan persepsi atau pandangan seseorang terhadap kepercayaan orang lain yang selanjutnya kan mempengaruhi minat untuk melakukan atau tidak melakukan tindakkan yang sedang dipertimbangkan. Pandangan seseorang yang berpengaruh terhadap suatu hal bisa mempengaruhi perilaku atau tindakan seseorang. Norma subyektif ini bisa muncul dalam bentuk positif sebagai dukungan sosial atau bahkan sebaliknya. Dan sumber utama munculnya ini adalah lingkungan.

Lingkungan seseorang memiliki pengaruh yang sangat besar terhadap perilaku orang tersebut. Sering kali tindakan yang dilakukan seseorang dilakukan atas pertimbangan diri sendiri atau bahkan atas pertimbangan orang lain. Keputusan yang dijatuhkan atas suatu pilihan sering diambil berdasar pertimbangan subyektif pihak lain yang dapat memberi dorongan untuk bertindak. Bahkan rencana keputusan untuk bertindak bisa juga gagal dilakukan jika tidak didukung oleh pertimbangan orang lain yang dianggap penting. Orang yang dianggap penting bisa datang dari keluarga atau pertemanan. Lingkungan tersebut merupakan sumber dari dukungan sosial. Dukungan sosial memiliki peran penting dalam mendukung kegiatan anak (Anjariah, 2006). Dari dukungan sosial yang diberikan kepada anak-anak yang ditunjukkan melalui sikap dan peran yang dijalankan anggota keluarga dapat mempengaruhi Tindakan dalam pengambilan keputusan yang diambil oleh anak, terlebih dalam hal pengambilan keputusan dalam pemilihan karier (Setiabudi, 2019). Hal ini juga terjadi pada apa yang ditampilkan dan dialami oleh mahasiswa wirausaha bahwa mereka memperoleh dukungan sosial dari keluarga mereka, terlebih dari orang tua mereka. dari hasil wawancara yang dilakukan kepada narasumber menyebut bahwa dukungan yang diberikan oleh orang tua mereka dapat memberikan semangat tersendiri dalam berwirausaha.

Periera, dkk. (2017) menyebut bahwa dukungan yang diberikan oleh orang tua memiliki beberapa dimensi, antara lain dimensi dukungan instrumental, dukungan emosional, dukungan penilaian dan dukungan informasi. Bentuk dukungan yang diberikan oleh orang tua mahasiswa wirausaha di lingkungan PIPS yang pertama adalah dukungan instrumental. Bentuk-bentuk dukungan instrumental yang diberikan oleh orang tua terhadap kegiatan wirausaha anak-anak mereka adalah dengan memberikan fasilitas untuk mendukung pengembangan usaha mereka. beberapa narasumber menyebut dukungan yang mereka didapatkan beragam. Sebagai contoh beberapa di antaranya diberikan bantuan finansial untuk mengembangkan usaha mereka. bantuan ini mereka gunakan untuk memperbanyak stok barang dan memproduksi barang. Selain adanya bantuan finansial beberapa narasumber menyebut bahwa mereka difasilitasi oleh orang tua mereka dengan disediakannya ruang untuk berwirausaha dan atau fasilitas pendukung lainnya misalnya rak tempat display barang, tentu saja ini terjadi pada mahasiswa yang saat ini tinggal dengan orang tua.

Kedua, dukungan emosional. Dukungan emosional juga sering kali diberikan oleh orang tua terhadap anak-anaknya yang berwirausaha. Adanya kepercayaan terhadap apa yang dilakukan anak-anak dalam berwirausaha merupakan salah satu contoh nyatanya. Hal ini dapat tercermin dari pemberian izin kepada anak-anak untuk melakukan aktivitas kewirausahaannya. Temuan 
di lapangan untuk dukungan ini beberapa narasumber mengaku bahwa dukungan diberikan oleh orang tua anak-anak dengan turut membantu kelancaran usaha anak dengan membantu produksi barang saat permintaan sedang banyak, bahkan ada juga yang turut serta melibatkan orang tua untuk berperan sebagai mitra mereka dalam berwirausaha. Hal ini menandakan adanya kenyamanan yang dimiliki oleh anak-anak terhadap orang tua mereka. Adanya kenyamanan dan kepercayaan yang dirasakan oleh anak dan orang tua dan sebaliknya merupakan hasil dari pendidikan di rumah.

Pendidikan merupakan aktivitas yang tidak terbatas pelaksanaannya di ruang kelas, akan tetapi pendidikan merupakan segala upaya yang dilakukan untuk mempersiapkan masa depan seseorang yang lebih baik Mursidin \& Arifin (2020). Di dalam lingkungan keluarga Pendidikan dilakukan setiap saat. Pendidikan dan penanaman nilai yang dilakukan oleh orang tua melalui modeling dan pembiasaan (Adi, et al., 2020). Modeling dan pembiasaan yang dilakukan oleh orang tua dapat membawa anak untuk dapat memiliki kehidupan yang lebih baik. keluarga juga merupakan salah satu faktor penentu dalam perkembangan pendidikan dan keberhasilan anak-anak (Ningrum, 2017).

Ketiga, dukungan informasi. Dukungan informasi yang diberikan oleh orang tua terhadap anak-anak mereka adalah dengan memberikan masukan atau saran-saran. Hasil wawancara di lapangan menemukan bahwa beberapa orang tua memberikan saran dan masukan terkait dengan usaha yang digeluti anak mereka. misalnya memberikan saran tentang apa yang harus dilakukan untuk inovasi usaha mereka, atau masukan tentang apa yang harus diperbuat dengan display atau stok lama serta nasehat tentang prinsip wirausaha dan tips trik supaya tidak jenuh dalam berwirausaha. Bentuk-bentuk dukungan tersebut merupakan dukungan informasi. Sebagaimana yang disampaikan oleh Maulida \& Dhina (2012) bahwa dukungan informasi atau nasehat dapat berbentuk verbal atau non verbal. Dengan adanya dukungan ini dapat berdampak pada kenyamanan fisik dan psikologis anak sehingga anak-anak akan merasa dicintai, diperhatikan dan dihargai oleh orang lain. Jika memiliki rasa tersebut maka akan membuat mereka termotivasi. Adanya motivasi ini selanjutnya akan memperkuat tingkah laku ke arah tujuan dalam diri (Maharani, et al., 2014). Dengan adanya motivasi seseorang dapat memantapkan perilaku mereka untuk fokus mencapai tujuan.

Keempat, dukungan Penilaian. Dukungan penilaian diberikan oleh orang tua dengan adanya penghargaan. Rata-rata informan mengaku bahwa memiliki anak yang mandiri dan tidak bergantung adalah suatu kebanggaan bagi mereka. Orang tua juga memberikan bimbingan terhadap anak-anak mereka. hal ini berlaku pada orang tua yang memiliki latar belakang wirausaha, sehingga di sini orang tua berperan sebagai mentor anak-anak dalam berwirausaha.

Selain keempat dukungan tersebut, para orang tua juga tidak melalaikan kewajiban mereka dengan dukungan dan motivasi untuk menyelesaikan pendidikan mereka. Narasumber mengatakan bahwa sering orang tua mereka mengingatkan tentang studi mereka. Namun walaupun demikian mereka tidak serta merta melarang dan membatasi minat anak-anak terhadap kewirausahaan. 


\section{Peran lingkungan keluarga dalam mengembangkan wirausaha muda}

\section{SIMPULAN}

Perilaku berwirausaha yang ditampilkan anak-anak dipengaruhi oleh lingkungan sosial, terlebih lingkungan keluarga. Pengaruh lingkungan keluarga yang bersifat positif tercermin dari dukungan keluarga. Dukungan keluarga yang diberikan kepada anak-anak wirausaha adalah dukungan instrumental, dukungan emosional, dukungan informasi, dan dukungan penilaian. Dukungan instrumental berupa pemberian dan penyediaan fasilitas yang diperlukan anak-anak untuk mengembangkan wirausaha. Dukungan emosional yang diberikan berupa pemberian kepercayaan dan pemberian izin untuk melakukan kegiatan berwirausaha. Dukungan informasi yang diberikan orang tua berupa pemberian masukan atau saran-saran untuk usaha anak-anaknya. Dukungan penilaian diberikan dengan diberikannya penghargaan dan bimbingan. Selain dukungan yang diberikan dalam tiga bentuk tersebut, para orang tua yang memiliki anak-anak yang bergelut dengan wirausaha juga tidak melupakan kewajiban mereka untuk memberikan dukungan terhadap kelangsungan studi mereka. Dengan hasil tersebut dapat dijadikan sebagai masukan untuk para orang tua yang memiliki anak dengan ketertarikan terhadap dunia wirausaha untuk dapat mengembangkan dan memberi dukungan terhadap potensi anak-anak, sehingga ke depannya dapat lahir pengusaha muda yang handal. Keterbatasan penelitian ini adalah hanya pada bagaimana dukungan orang tua terhadap wirausaha anak, penting kiranya untuk peneliti selanjutnya mencari tahu atau meneliti tentang bagaimana mahasiswa wirausaha tersebut untuk tetap mempertahankan atau meningkatkan motivasi dalam berwirausaha.

\section{DAFTAR PUSTAKA}

Adi, K. R., Idris \& Rosyidah, F., 2020. Internalisasi Nilai-Nilai Kewirausahaan Etnis Madura. JTP2IPS, 5(1), pp. 1-9.

Ajzen, I., 1991. The theory of planned behavior. Organizational Behavior and Human Decision Processes, 50(2), pp. 179-211.

Anjariah, S., 2006. Prestasi Belajar Siswa Ditinjau dari Dukungan Sosial Orang Tua. Jurnal Psikologi, 2(1).

Creswell, J., 2015. Penelitian Kualitatif dan Desain Riset: Memilih di Antara Lima Pendekatan. 3rd penyunt. Yogyakarta: Pustaka Pelajar.

Frinces, Z. H., 2010. Pentingnya Profesi Wirausaha di Indonesia. Jurnal Ekonomi \& Pendidikan, 7(1), pp. 34-57.

Jogiyanto, 2007. Sistem Informasi Keperilakuan. Yogyakarta: ANDI.

Liputan6.com, 2019. Jumlah Pelamar CPNS 2019 Tembus 5,05 Juta Orang. [Online] Available at: https://www.liputan6.com/bisnis/read/4129332/jumlah-pelamar-cpns2019-tembus-505-juta-orang

[Diakses 18 Maret 2021]. 
Maharani, Dalimunthe, R. F. \& Qamariah, I., 2014. ROLE OF PARENTS IN CHILDRENS' CAREER SELECTION AS AN ENTREPRENEUR. International Journal of Economics, Commerce and Management, II(12), pp. 1-11.

Mahyarni, 2013. THEORY OF REASONED ACTION DAN THEORY OF PLANNED BEHAVIOR (Sebuah Kajian Historis tentang Perilaku). Jurnal El-Riyasah, 4(1), pp. 1323.

Maulida, S. R. \& Dhina, D. R., 2012. HUBUNGAN ANTARA KEPERCAYAAN DIRI DAN DUKUNGAN ORANG TUA DENGAN MOTIVASI BERWIRAUSAHA PADA SISWA SMK. Jurnal Psikologi, 11(2), pp. 2-8.

Miles, M. \& Huberman, A., 1992. Analisis Data Kualitatif. Jakarta: UI-Press.

Mursidin \& Arifin, 2020. Pendidikan Kewirausahaan. Rawamangun: PT Bumi Aksara.

Nagel, P. J. F., 2016. Pengembangan Jiwa dan kecerdasan Wirausaha untuk Kemandirian Bangsa. Surakarta, Universitas Muhammadiyah Surakarta.

Ningrum, M. A., 2017. PERAN KELUARGA DALAM MENUMBUHKAN JIWA WIRAUSAHA SEJAK USIA DINI. Jurnal Pendidikan (Teori dan Praktik), 2(1), pp. 3943.

Periera, A., Mashabi, N. A. \& Muhariati, M., 2017. Pengaruh Dukungan Orang Tua terhadap Minat Anak dalam Berwirausaha (Pada Siswa SMK Strada Koja, Jakarata Utara). Jurnal Kesejahteraan keluarga dan Pendidikan, 4(2), pp. 70-76.

Ratumbuysang, M. F. N. G. \& Rasyid, A. A., 2015. Peranan orang tua, lingkungan, dan pembelajaran kewirausahaan terhadap kesiapan berwirausaha. Jurnal Pendidikan Vokasi, 5(1), pp. 15-26.

Setiabudi, K. J., 2019. Pengaruh Dukungan Keluarga dan Kepribadian Wirausaha Terhadap Niat Berwirausaha Mahasiswa Progra Studi Manajemen Terakreditasi 'A" Pada Perguruan Tinggi Swasta di Kota Surabaya. AGORA, 7(1).

Wahab, R., 2005. Peran Orang Tua dan Pendidikan dalam Mengoptimalkan Potensi Anak Berbakat Akademik. Semarang, DEMA Psikologi Undip. 